\title{
Evaluating the Accumulation of Antioxidant and Macro- and Trace Elements in Vaccinium myrtillus L.
}

\author{
Marta Kandziora-Ciupa ${ }^{1}$ (D) Marzena Dabioch $^{2}$ (D) Aleksandra Nadgórska-Socha ${ }^{1}$ (D)
}

Received: 28 May 2021 / Accepted: 21 October 2021 / Published online: 29 October 2021

(C) The Author(s) 2021

\begin{abstract}
This study was conducted in order to characterise the accumulation ability of Vaccinium myrtillus $\mathrm{L}$ for trace elements such as $\mathrm{Al}, \mathrm{Cd}, \mathrm{Cu}, \mathrm{Fe}, \mathrm{Mn}, \mathrm{Pb}$ and $\mathrm{Zn}$ and selected macroelements $\mathrm{Ca}, \mathrm{K}, \mathrm{Mg}, \mathrm{Na}$ and $\mathrm{P}$. The accumulation of nutrient elements and trace elements (ANE and ATE) and changes in the ecophysiological responses in bilberry in differently polluted areas were compared. The accumulation of the elements in the roots, stems and leaves of bilberry from four sites (in the nearest vicinity of a zinc smelter, a Mining and Metallurgical Plant, a main road with a high traffic volume and an unprotected natural forest community) were measured using optical emission spectrometry with excitation using inductively coupled argon plasma after wet acid digestion. The highest $\mathrm{Cd}, \mathrm{Cu}, \mathrm{Pb}$ and $\mathrm{Zn}$ concentrations were found in the V. myrtillus samples that were growing under the influence of the emissions from the zinc smelter. Moreover, the level of the total accumulated trace metals (ATE-17.09 mmol $_{\mathrm{c}} \mathrm{kg}^{-1}$ ) was also highest for the bilberry at this site. However, in the same area, the sum of the accumulated macronutrients (ANE-296.92 $\mathrm{mmol}_{\mathrm{c}} \mathrm{kg}^{-1}$ ) was lower than at the other sampling sites. An EF $>2$ was found for $\mathrm{Cd}, \mathrm{Pb}, \mathrm{Zn}$ and $\mathrm{Mn}$, which suggests that bilberries may be enriched in these metals. According to the translocation factor, V. myrtillus was an accumulator of $\mathrm{Cd}, \mathrm{Zn}$ and $\mathrm{Mn}$. An analysis of the ecophysiological responses showed that the greatest concentration of ascorbic acid was found in the leaves of $V$. myrtillus at the most contaminated site $\left(3.32 \mathrm{mg} \mathrm{g}^{-1}\right.$ fresh weight). There were no significant differences in the total phenols between the contaminated and non-contaminated sites. However, the lowest value of the total phenolic content $\left(490.77 \mathrm{mg} \mathrm{g}^{-1}\right.$ dry weight) was recorded at the site where the highest Fe concentration was detected in the leaves. A significantly positive correlation between the $\mathrm{Cd}, \mathrm{Pb}$ and $\mathrm{Zn}$ concentrations and a strong negative correlation between the Mn concentration and ascorbic acid content in the leaves of bilberry was also observed. The results provide evidence that the ANE method, which is used to interpret the chemical composition of bilberry has made determining the impact of toxic trace metals on the mineral composition of $V$. myrtillus significantly easier and also that a non-enzymatic antioxidant such as ascorbic acid can be a good biomarker for determining the oxidative stress that is caused by toxic trace metals.
\end{abstract}

Keywords Bilberry $\cdot$ Antioxidants $\cdot$ Accumulation $\cdot$ Forest pollution $\cdot$ Toxic elements

\section{Introduction}

Marta Kandziora-Ciupa

marta.kandziora-ciupa@us.edu.pl

1 Ecology, Institute of Biology, Biotechnology and Environmental Protection, Faculty of Natural Sciences, University of Silesia in Katowice, Bankowa 9, 40-007 Katowice, Poland

2 Department of Analytical Chemistry, Institute of Chemistry, Faculty of Science and Technology, University of Silesia in Katowice, Szkolna 7, 40-006 Katowice, Poland

Forest ecosystems, especially those of central Europe and other regions, have been exposed to pollution for decades and are characterised by their high capacity to filter contaminants such as toxic trace metals that are transported within the atmosphere [1,2]. The ground vegetation of forest ecosystems (defined as all terricolous plants-herbs, shrubs and trees) is included in the intensive monitoring of forest ecosystems in ICP Forests (International Co-operative Programme on Assessment and Monitoring of Air Pollution Effects on Forests), which is a particularly important element that provides information on any changes in a forest 
ecosystem and as a specific target for calculating critical loads/levels [3].

In the understorey of conifer forests in Europe and Northern Asia, Vaccinium myrtillus L. (bilberry) is a key and widely diffused long-lived clonal dwarf shrub species that belongs to the family Ericaceae and the genus Vaccinium [4-6]. It plays an essential role in nutrient cycling and is an important food source for many insects, birds and mammals, thus forming a link between the soil metal pool and the upper trophic levels in polluted environments [7]. Bilberry is a species that is relatively tolerant to a variety of environmental stressors such as long-term toxic trace metal pollution. At heavily polluted sites, V. myrtillus is able to grow, regenerate and spread [7-10], which enables bilberry to serve as model species of the forest floor of boreal forests that have been exposed to metal pollution. Additionally, bilberry can easily take up metals from the upper soil layer because its root system is generally shallow and this is the layer in which the metals from the atmosphere accumulate [7-9].

Anthropogenic trace elements are persistent and highly toxic pollutants that are serious risks to plants and animals and after they enter the food chain, also for humans [11, 12]. Toxic trace metals are listed as priority pollutants in many regions and ecosystems. They have been proven to be a great threat to plants; they affect the functions of many enzymes and proteins, disturb metabolism, exhibit phytotoxicity and eventually reduce growth due to physiological and biochemical processes [12,13]. Elevated levels of toxic trace metals are associated with the increased generation of reactive oxygen species (ROS) [14] and oxidative stress, which leads, e.g., to the growth of membrane permeability and the leakage of ions, changes in the enzymatic activity, disturbances in the processes of photosynthesis and respiration, damage to cell protein, lipids and nucleic acid. In order to scavenge ROS and avoid oxidative damage, plants protect themselves with enzymatic and non-enzymatic (including ascorbic acid and phenolic compounds) mechanisms [15]. The responses of the antioxidant system/ecophysiological responses in plants can provide evidence of the early symptoms of the damage, which precede the morphological or ultrastructural damage that is caused by the metals. Therefore, early environmental stress could be estimated based on ecophysiological responses of a plant, which might be useful in toxic trace element pollution biomonitoring $[16,17]$. Understanding the mechanisms that underlie the resistance or tolerance of plants to different stress factors, including toxic trace metals, is extremely important in the era of global warming, where the mobility of pollutants in the environment increases [18].

It is, therefore, reasonable to find and select the most useful indicators that are applicable in the bioindication of a forest environment. The research hypothesis of this study assumes that an environmental contamination with trace elements influences the pattern of accumulated elements and causes changes in a plant's antioxidants, which can be used in the bioindication of forest ecosystems. Therefore, this study was conducted to characterise the accumulation ability of Vaccinium myrtillus L. We compared the accumulation of nutrient elements and trace elements (ANE and ATE) and changes in the ecophysiological responses in bilberry in differently polluted areas.

The detailed objectives of this study were (1) to document and compare the nutrient (ANE) and trace element (ATE) concentrations in the leaves, stems and roots of $V$. myrtillus that was growing on metal-polluted and relatively unpolluted sites, (2) to evaluate and compare the distribution patterns and the accumulation efficiency of toxic trace metals in $V$. myrtillus and (3) to estimate the ecophysiological responses to stress that are caused by toxic trace metals in the leaves of bilberry growing under field conditions.

\section{Material and Methods}

\section{Study Area}

The study was performed around a middle-aged Scots pine (Pinus sylvestris L.) forest, which has mixed stands with birch (Betula pendula L.), European beech (Fagus sylvatica L.) and pedunculate oak (Quercus robur L.) and sandy acidic soils. The plant materials was collected from three differently polluted sites (in the nearest vicinity of the zinc smelter "Miasteczko Śląskie" in Miasteczko Śląskie (active since 1968 ) at $50^{\circ} 31^{\prime} 22.655^{\prime \prime} \mathrm{N} 18^{\circ} 56^{\prime} 8.699^{\prime \prime} \mathrm{E}(\mathrm{M})$, in the nearest vicinity of the ZGH "Boleslaw" Mining and Metallurgical Plant in Bukowno (active since 1955) at 50 $15^{\prime} 55.6^{\prime \prime} \mathrm{N}$ $19^{\circ} 26^{\prime} 34.64^{\prime \prime} \mathrm{E}$ (B), in Katowice-Kostuchna in the vicinity of a main road with a high traffic volume at $50^{\circ} 11^{\prime} 42.75^{\prime \prime}$ $\mathrm{N} 19^{\circ} 026.363^{\prime \prime} \mathrm{E}(\mathrm{K})$ and in an unprotected natural forest community in Kokotek at 50 36'21.287" N 18 42'59.806" $\mathrm{E}(\mathrm{KO})$, which was considered the control site. All of the sites are in the Ślaskie or Małopolskie provinces in southern Poland (Fig. 1) [19].

\section{Sample Collection}

Vaccinium myrtillus L. leaves, stems and roots were collected in May 2017. Each sampling site consisted of a $25 \times 25 \mathrm{~m}$ square from within which three replicates of fully mature and undamaged leaves, stems and roots were collected from at least 20 different bilberry specimens. After collection, the samples were placed in plastic bags, deposited on ice and transported to the laboratory. 
Fig. 1 Location map of sampling sites (Kandziora-Ciupa et al. 2021)

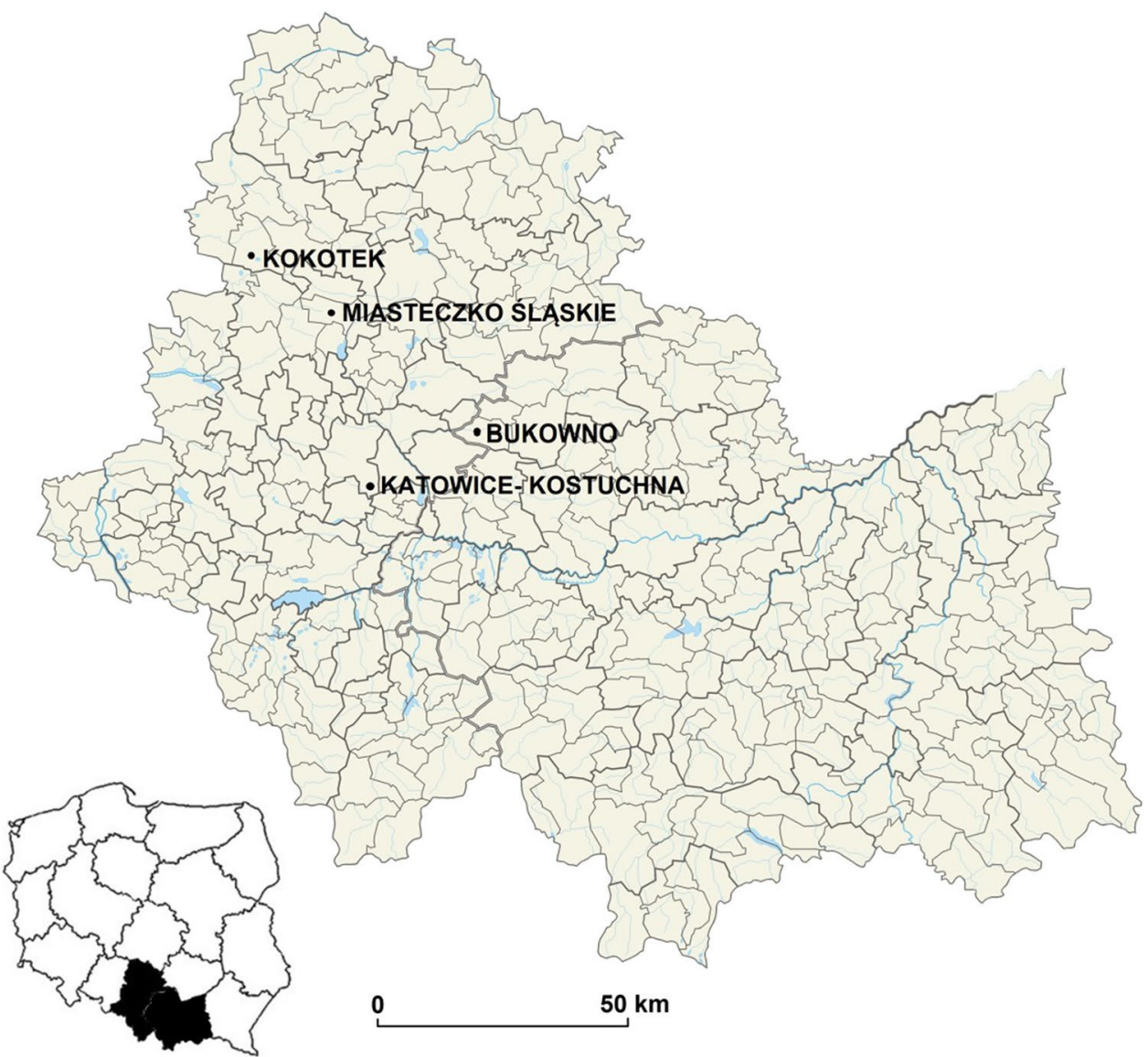

\section{Analysis of Macro- and Toxic Trace Element Concentration in the Plant Samples}

In order to determine the macroelement $(\mathrm{Ca}, \mathrm{K}, \mathrm{Mg}, \mathrm{Na}$, $\mathrm{P})$ and toxic trace element ( $\mathrm{Al}, \mathrm{Cd}, \mathrm{Cu}, \mathrm{Pb}, \mathrm{Zn}, \mathrm{Fe}, \mathrm{Mn}$ ) concentrations in the samples of bilberry (leaves, stems and roots), the plant material was washed with tap water to remove any substrate and dust deposits, then rinsed twice with distilled water and dried at $105^{\circ} \mathrm{C}$. A 0.25 -g portion of dry plant material in digestion vessels was treated with $4 \mathrm{ml}$ concentrated nitric acid and was then pre-digested for $24 \mathrm{~h}$ at room temperature. Next, the tubes were placed in digital dry baths (The Labnet Digital Dry Baths, dual block; temperature range: $+5^{\circ}$ above ambient temperature to $150^{\circ} \mathrm{C}$; temperature uniformity: $\pm 0.2^{\circ} \mathrm{C}$ ) and heated to $120{ }^{\circ} \mathrm{C}$ until the samples were completely digested. After cooling to room temperature, the digested samples were filtered into $50 \mathrm{ml}$ plastic bottles and diluted to $25 \mathrm{ml}$ with deionised water [20]. The levels of the toxic trace elements and macroelements were measured using optical emission spectrometry with excitation using inductively coupled argon plasma (SPECTROBLUE ICP-OES, Spectro Analytical Instruments, Germany). The optimum measurement conditions are listed in Table 1 . The wavelength,
Table 1 Measurement conditions for ICP-OES

\begin{tabular}{|c|c|}
\hline Rf power, kW & 1.4 \\
\hline Frequency, $\mathrm{MHz}$ & 27.12 \\
\hline Plasma torch & Quartz \\
\hline Plasma gas flow, $\mathrm{L} \min ^{-1}$ & 12.0 \\
\hline Auxiliary gas flow, $\mathrm{L} \mathrm{min}-1$ & 0.8 \\
\hline Nebulizer gas flow, $\mathrm{L} \mathrm{min}-1$ & 0.8 \\
\hline Crossflow nebulizer, bar & 2.4 \\
\hline Sample uptake $\mathrm{mL} \min ^{-1}$ & 1 \\
\hline Number of replicates & 3 \\
\hline Read delay time, s & 3 \\
\hline Scope of the polichromator, $\mathrm{nm}$ & $\begin{array}{l}165-285 \\
285-470\end{array}$ \\
\hline Holographic grid, grooves $\mathrm{mm}^{-1}$ & 36001800 \\
\hline Integration time, $\mathrm{s}$ & 3 \\
\hline
\end{tabular}

LOD (limit of detection), LOQ (limit of quantification) and $R^{2}$ (correlation coefficients) for the determined elements using the ICP-OES method in this study are listed in Table 2. The quality of the analytical procedure was determined using a reference material (Certified reference Material CTA-OTL-1 Oriental Tobacco Leaves) with the same quantities of samples. 
Table 2 The wavelength, LOD, LOQ, and $R^{2}$ for the determined elements

\begin{tabular}{lllll}
\hline Element & Wavelength $(\mathrm{nm})$ & LOD & LOQ & $R^{2}$ \\
\hline $\mathrm{Al}$ & 176.641 & 0.0092 & 0.0183 & 0.99997 \\
$\mathrm{Ca}$ & 422.673 & 0.0090 & 0.0181 & 0.99996 \\
$\mathrm{Cd}$ & 214.438 & 0.0003 & 0.0007 & 0.99995 \\
$\mathrm{Cu}$ & 324.754 & 0.0053 & 0.0106 & 0.99990 \\
$\mathrm{Fe}$ & 275.573 & 0.0091 & 0.0182 & 0.99997 \\
$\mathrm{~K}$ & 766.491 & 0.1007 & 0.2015 & 0.99999 \\
$\mathrm{Mg}$ & 279.553 & 0.0005 & 0.0011 & 0.99982 \\
$\mathrm{Mn}$ & 259.373 & 0.0008 & 0.0016 & 0.99998 \\
$\mathrm{Na}$ & 589.592 & 0.0009 & 0.0018 & 0.99992 \\
$\mathrm{P}$ & 178.287 & 0.0316 & 0.0632 & 0.99994 \\
$\mathrm{~Pb}$ & 168.215 & 0.0072 & 0.0143 & 0.99989 \\
$\mathrm{Zn}$ & 213.856 & 0.0092 & 0.0184 & 0.99996 \\
\hline
\end{tabular}

$L O D$ limit of detection, $L O Q$ limit of quantification, $R^{2}$ correlation coefficients

\section{The Accumulation of the Nutrient Elements and the Trace Elements}

The accumulation of the nutrient elements and the trace elements (ANE and ATE) in the studied plants was analysed according to the method by [21]. To calculate the sum of the elements, the values describing the amount of each element were converted into equivalents. The sum of the elements in $\mathrm{mmol}_{\mathrm{c}} \mathrm{kg}^{-1}$ was calculated according to the following formula:

$Y=\sum_{i=1}^{i} \frac{Z}{z}$

where $\mathrm{Z}$ is the element content in $\mathrm{mg} \mathrm{kg}^{-1}$ and $z$ is the atomic mass/valence of an ion

$Y=\frac{N}{14}+\frac{P}{31}+\frac{K}{39}+\cdots+\frac{C u}{31.8}+\frac{M n}{27.5}+\ldots$

After estimating the sum of the accumulation, the percentage of each element $(X)$ was calculated:

$X_{z}=\frac{\left(\frac{Z}{z}\right) \times 100}{Y}$

\section{Metal Accumulation Efficiency}

To evaluate the metal accumulation in the plant samples, the translocation factor (TF) and enrichment factor (EF) were calculated, results were expressed on dried weight. The TF is the ratio of metal concentration in the shoots (leaves + stems) and the roots. A TF $>1$ indicates that a plant translocates metals effectively from the roots to the shoot [22]. The EF shows the degree of the accumulation of toxic trace metals in the plants growing at the contaminated sites compared to those growing at the non-contaminated sites. The $\mathrm{EF}$ was calculated as $\mathrm{EF}=\mathrm{C} / \mathrm{C}$ where $\mathrm{C}$ and $\mathrm{C}$ refer to the metal concentrations $\left(\mathrm{mg} \mathrm{kg}^{-1}\right)$ in the Vaccinium myrtillus shoots (leaves + stems) from the contaminated and the non-contaminated site [22]. The values of the factors mentioned above help to specify the strategy of metal accumulation in the plants and were calculated for the main metals $(\mathrm{Cd}, \mathrm{Mn}, \mathrm{Pb}$ and $\mathrm{Zn}$ ),

\section{Analysis of the Ecophysiological Parameters of the Plants}

The estimation of the reducing capacity of the plants, as expressed by the total phenolic content, might indicate the antioxidative potential and the resistance of the plants to environmental stress. The soluble phenolics were determined by homogenizing a fresh leaf $(0.3 \mathrm{~g})$ at $4{ }^{\circ} \mathrm{C}$ in $80 \%$ methanol to a final volume of $3 \mathrm{ml}$ and then centrifuged at $12,000 \times g$ for $15 \mathrm{~min}$ at $4{ }^{\circ} \mathrm{C}$. The assay mixture contained $30 \mu \mathrm{l}$ of the supernatant, $470 \mu \mathrm{l}$ of redistilled water, $975 \mu \mathrm{l}$ of $2 \% \mathrm{Na}_{2} \mathrm{CO}_{3}$ and $25 \mu \mathrm{l}$ of a 2-N Folin-Ciocalteu reagent. The samples were incubated for $1 \mathrm{~h}$ at $45^{\circ} \mathrm{C}$ and the absorbance was measured at $750 \mathrm{~nm}$. The total phenol content was calculated based on a standard curve that was prepared using gallic acid [23].

The ascorbic acid content was calculated using the formula given by [24]:

Ascorbic acid $\left(\mathrm{mg} \times \mathrm{g}^{-1}\right.$ fresh weight $)=\frac{\left(\mathrm{E}_{\mathrm{o}}-\mathrm{E}_{\mathrm{s}}-\mathrm{E}_{\mathrm{t}}\right) \mathrm{V}}{\mathrm{W} \times 100} \times 100$

where $V$ is the volume of the extract, $W$ is the weight of the fresh leaf sample (g) and $E_{\mathrm{o}}, E_{\mathrm{s}}$ and $E_{\mathrm{t}}$ are the optical densities of a blank sample, a plant sample, and a sample with ascorbic acid, respectively.

\section{Statistical Analysis}

The data concerning macroelements, toxic trace elements and other ecophysiological parameters were examined for normality and homogeneity of variance. When there was a normal distribution and variance homogeneity, the data was analysed using ANOVA and the treatments were treated as the independent variables. Any significant statistical differences of all of the variables were established using the Tukey`s test (ANOVA; Statistica 10 package). Pearson`s correlation coefficient was calculated to assess the relationship between the estimated metal concentrations and the ecophysiological parameters in the bilberry 
leaves. CANOCO 4.5 was used to perform the principal component analysis, which assessed the similarities and relationships between the metal concentrations and the ecophysiological parameters in the studied areas.

Table 3 The concentrations of macroelement $\left(\mathrm{mg} \mathrm{kg}^{-1}\right.$ d.w.) in the various plant tissue of $V$. myrtillus (mean values)

\begin{tabular}{clllll}
\hline \multicolumn{1}{c}{ Ca } & K & $\mathrm{Mg}$ & $\mathrm{Na}$ & $\mathrm{P}$ \\
\hline Leaves & & & & & \\
M & $2938.77 \mathrm{a}$ & $3460.94 \mathrm{~b}$ & $520.47 \mathrm{a}$ & $1.89 \mathrm{a}$ & $3276.70 \mathrm{a}$ \\
$\mathrm{B}$ & $3789.63 \mathrm{ab}$ & $3900.60 \mathrm{c}$ & $1057.99 \mathrm{~b}$ & $2.21 \mathrm{a}$ & $3128.49 \mathrm{a}$ \\
K & $3638.58 \mathrm{ab}$ & $4991.42 \mathrm{~d}$ & $1220.66 \mathrm{c}$ & $1.70 \mathrm{a}$ & $3174.06 \mathrm{a}$ \\
KO & $4008.55 \mathrm{~b}$ & $3309.94 \mathrm{a}$ & $1331.88 \mathrm{~d}$ & $1.58 \mathrm{a}$ & $3324.81 \mathrm{a}$ \\
Stems & & & & & \\
M & $4402.27 \mathrm{~b}$ & $1337.38 \mathrm{a}$ & $435.89 \mathrm{a}$ & $2.51 \mathrm{~b}$ & $1400.63 \mathrm{a}$ \\
B & $6466.70 \mathrm{c}$ & $1672.39 \mathrm{~b}$ & $936.66 \mathrm{~b}$ & $2.99 \mathrm{~b}$ & $1581.34 \mathrm{a}$ \\
K & $2124.61 \mathrm{a}$ & $2487.89 \mathrm{c}$ & $526.77 \mathrm{a}$ & $2.76 \mathrm{~b}$ & $1866.24 \mathrm{a}$ \\
KO & $4794.03 \mathrm{bc}$ & $1881.48 \mathrm{~b}$ & $838.31 \mathrm{~b}$ & $1.88 \mathrm{a}$ & $2244.97 \mathrm{~b}$ \\
Roots & & & & & \\
M & $1749.80 \mathrm{~b}$ & $817.42 \mathrm{~b}$ & $228.95 \mathrm{a}$ & $1.54 \mathrm{a}$ & $1038.79 \mathrm{~b}$ \\
B & $1062.78 \mathrm{a}$ & $950.02 \mathrm{a}$ & $240.07 \mathrm{ab}$ & $2.11 \mathrm{~b}$ & $830.16 \mathrm{a}$ \\
K & $1075.66 \mathrm{a}$ & $1452.52 \mathrm{c}$ & $287.27 \mathrm{~b}$ & $2.90 \mathrm{c}$ & $1059.97 \mathrm{~b}$ \\
KO & $1383.15 \mathrm{ab}$ & $959.96 \mathrm{a}$ & $263.11 \mathrm{ab}$ & $1.72 \mathrm{a}$ & $995.62 \mathrm{~b}$ \\
\hline
\end{tabular}

The different letters denote significant differences between the macroelement concentrations in the same organ $(p<0.05)$

$M$ Miasteczko Śląskie. $B$ Bukowno, $K$ Katowice-Kostuchna, $K O$ Kokotek

\section{Results}

The results of the bioaccumulation of the trace metals and macroelements that were analysed in the leaves, stems and roots of $V$. myrtillus are listed in Tables 3 and 4. Generally, the levels of the toxic trace element were significantly higher in the most polluted area (M). An exception to this was Mn, which had markedly higher values at the KatowiceKostuchna site (K). The levels of the toxic trace elements ( $\mathrm{Al}, \mathrm{Cd}, \mathrm{Cu}, \mathrm{Fe}, \mathrm{Mn}, \mathrm{Pb}, \mathrm{Zn}$ ) in the different $V$. myrtillus organs from the most polluted area followed the general pattern: roots $>$ stems $>$ leaves (Table 4). Again, Mn was an exception because at the site where its highest concentration was found $(\mathrm{K})$, this pattern was completely the opposite: leaves $>$ stems $>$ roots (Table 4 ).

The accumulation of the nutrient and trace elements (ANE and ATE) in the V. myrtillus shoots was calculated separately for the macro- and toxic trace elements. At the most contaminated site (M), the average level of accumulated macronutrients was lowest compared to the other areas (Table 5). A higher, almost two-fold, value of ANE was found for the V. myrtillus at B, K and KO sites (Table 5). Quite the opposite was found in the case of the total accumulated trace metals (ATE), where a higher value was detected for the V. myrtillus at the contaminated sites, especially at Miasteczko Śląskie (three-fold higher than at the noncontaminated site in Kokotek-KO) (Table 6). At the most contaminated site $(\mathrm{M})$, the percentages of $\mathrm{Cd}, \mathrm{Pb}$ and $\mathrm{Zn}$ were higher than the percentages that were obtained for the bilberry that had been collected at the other sites (Table 6).
Table 4 The concentrations of trace elements ( $\mathrm{mg} \mathrm{kg}^{-1}$ d.w.) in the various plant tissue of $V$. myrtillus (mean values)

\begin{tabular}{clllllll}
\hline & $\mathrm{Al}$ & $\mathrm{Cd}$ & $\mathrm{Cu}$ & $\mathrm{Fe}$ & $\mathrm{Mn}$ & $\mathrm{Pb}$ & $\mathrm{Zn}$ \\
\hline Leaves & & & & & & & \\
M & $107.17 \mathrm{a}$ & $9.81 \mathrm{~b}$ & $9.06 \mathrm{~b}$ & $108.58 \mathrm{~b}$ & $39.91 \mathrm{a}$ & $232.08 \mathrm{~b}$ & $332.26 \mathrm{~b}$ \\
$\mathrm{~B}$ & $148.47 \mathrm{~b}$ & $0.34 \mathrm{a}$ & $5.78 \mathrm{ab}$ & $310.97 \mathrm{~d}$ & $282.74 \mathrm{~b}$ & $17.86 \mathrm{a}$ & $120.24 \mathrm{a}$ \\
$\mathrm{K}$ & $175.94 \mathrm{c}$ & $0.41 \mathrm{a}$ & $2.17 \mathrm{ab}$ & $141.42 \mathrm{c}$ & $1124.81 \mathrm{~d}$ & $4.62 \mathrm{a}$ & $12.17 \mathrm{a}$ \\
KO & $98.23 \mathrm{a}$ & $0.46 \mathrm{a}$ & $3.62 \mathrm{a}$ & $59.57 \mathrm{a}$ & $428.07 \mathrm{c}$ & $4.55 \mathrm{a}$ & $16.36 \mathrm{a}$ \\
Stems & & & & & & & \\
M & $181.82 \mathrm{a}$ & $17.16 \mathrm{~b}$ & $11.13 \mathrm{c}$ & $133.39 \mathrm{~b}$ & $66.85 \mathrm{a}$ & $390.44 \mathrm{~b}$ & $737.85 \mathrm{c}$ \\
$\mathrm{B}$ & $140.30 \mathrm{a}$ & $0.84 \mathrm{a}$ & $2.33 \mathrm{~b}$ & $238.71 \mathrm{c}$ & $380.32 \mathrm{~b}$ & $22.20 \mathrm{a}$ & $361.66 \mathrm{~b}$ \\
$\mathrm{~K}$ & $142.13 \mathrm{a}$ & $0.53 \mathrm{a}$ & $0.69 \mathrm{a}$ & $95.57 \mathrm{a}$ & $760.73 \mathrm{~d}$ & $6.50 \mathrm{a}$ & $25.20 \mathrm{a}$ \\
KO & $119.71 \mathrm{a}$ & $0.50 \mathrm{a}$ & $2.05 \mathrm{ab}$ & $56.40 \mathrm{a}$ & $507.17 \mathrm{c}$ & $6.91 \mathrm{a}$ & $72.27 \mathrm{a}$ \\
Roots & & & & & & & \\
M & $214.38 \mathrm{c}$ & $26.51 \mathrm{~b}$ & $18.82 \mathrm{~b}$ & $264.66 \mathrm{~b}$ & $93.30 \mathrm{a}$ & $668.31 \mathrm{~b}$ & $1003.10 \mathrm{~b}$ \\
$\mathrm{~B}$ & $129.33 \mathrm{~b}$ & $0.29 \mathrm{a}$ & $1.59 \mathrm{a}$ & $117.87 \mathrm{a}$ & $160.33 \mathrm{~b}$ & $32.43 \mathrm{a}$ & $126.40 \mathrm{a}$ \\
$\mathrm{K}$ & $196.48 \mathrm{~b}$ & $0.37 \mathrm{a}$ & $1.14 \mathrm{a}$ & $151.27 \mathrm{a}$ & $429.46 \mathrm{~d}$ & $28.62 \mathrm{a}$ & $15.33 \mathrm{a}$ \\
KO & $113.19 \mathrm{a}$ & $1.29 \mathrm{a}$ & $2.29 \mathrm{a}$ & $101.08 \mathrm{a}$ & $204.56 \mathrm{c}$ & $48.27 \mathrm{a}$ & $66.23 \mathrm{a}$ \\
\hline
\end{tabular}

The different letters denote significant differences between the element concentrations in the same organ $(p<0.05)$

$M$ Miasteczko Śląskie, $B$ Bukowno, $K$ Katowice-Kostuchna, $K O$ Kokotek 
Table 5 Accumulation of nutrient elements (ANE) in $V$. myrtillus shoots

\begin{tabular}{lllllll}
\hline Stands & $\begin{array}{l}\text { ANE macroelements } \\
{\left[\mathrm{mmol}_{\mathrm{c}} \mathrm{kg}^{-1}\right]}\end{array}$ & $\mathrm{Ca}[\%]$ & $\mathrm{K}[\%]$ & $\mathrm{Mg}[\%]$ & $\mathrm{Na}[\%]$ & $\mathrm{P} \mathrm{[ \% ]}$ \\
\hline M & 296.92 & 13.74 & 16.59 & 4.03 & 0.02 & 19.83 \\
B & 463.98 & 14.04 & 14.81 & 6.49 & 0.01 & 15.00 \\
K & 462.21 & 14.61 & 20.55 & 8.12 & 0.01 & 16.50 \\
KO & 467.40 & 15.37 & 13.01 & 8.45 & 0.01 & 16.50 \\
\hline
\end{tabular}

$M$ Miasteczko Śląskie, $B$ Bukowno, $K$ Katowice-Kostuchna, $K O$ Kokotek

\begin{tabular}{lllllllll}
\hline Stands & $\begin{array}{l}\text { ATE trace ele- } \\
\text { ments [mmol } \\
\left.\mathrm{kg}^{-1}\right]\end{array}$ & $\mathrm{Al}[\%]$ & $\mathrm{Cd}[\%]$ & $\mathrm{Cu}[\%]$ & $\mathrm{Fe}[\%]$ & $\mathrm{Mn}[\%]$ & $\mathrm{Pb}[\%]$ & $\mathrm{Zn} \mathrm{[ \% ]}$ \\
\hline $\mathrm{M}$ & 17.09 & 0.74 & 0.016 & 0.0003 & 0.36 & 0.14 & 0.21 & 0.95 \\
$\mathrm{~B}$ & 11.97 & 0.82 & 0.0004 & 0.0001 & 0.83 & 0.76 & 0.01 & 0.27 \\
$\mathrm{~K}$ & 8.53 & 1.05 & 0.0006 & 0.0001 & 0.41 & 3.30 & 0.004 & 0.03 \\
$\mathrm{KO}$ & 5.11 & 0.56 & 0.0006 & 0.0001 & 0.16 & 1.20 & 0.003 & 0.04 \\
\hline
\end{tabular}

$M$ Miasteczko Śląskie, $B$ Bukowno, $K$ Katowice-Kostuchna, $K O$ Kokotek
Table 6 Accumulation of trace elements (ATE) in V. myrtillus shoots
Table 7 Translocation factor (TF) and Enrichment factor (EF) in $V$. myrtillus shoots

\begin{tabular}{ccccc}
\hline Stands & $\mathrm{Cd}$ & $\mathrm{Mn}$ & $\mathrm{Pb}$ & $\mathrm{Zn}$ \\
\hline \multicolumn{2}{l}{ Translocation factor } \\
$\mathrm{M}$ & 1.02 & 1.14 & 0.93 & 1.07 \\
$\mathrm{~B}$ & 4.04 & 4.14 & 1.24 & 3.81 \\
$\mathrm{~K}$ & 2.53 & 4.39 & 0.39 & 2.44 \\
$\mathrm{KO}$ & 0.74 & 4.57 & 0.24 & 1.34 \\
Enrichment factor & & & \\
$\mathrm{M}$ & 28.01 & 0.11 & 54.30 & 12.07 \\
$\mathrm{~B}$ & 1.23 & 0.71 & 3.49 & 5.44 \\
$\mathrm{~K}$ & 0.97 & 2.02 & 0.97 & 0.42 \\
$\mathrm{KO}$ & 1.00 & 1.00 & 1.00 & 1.00 \\
\hline
\end{tabular}

$M$ Miasteczko Śląskie, $B$ Bukowno, $K$ Katowice-Kostuchna, $K O$ Kokotek

The mean values of the translocation factor (TF) and enrichment factor (EF) for bilberry are listed in Table 7. A translocation factor above $1(\mathrm{TF}>1)$ in $V$. myrtillus was observed for almost all of the investigated metals at all of the areas; the exceptions were $\mathrm{Pb}$, for which $\mathrm{TF}>1$ was found for only one sampling site (B, Table 7) and $\mathrm{Cd}$, for which $\mathrm{TF}$ was below one at only the non-contaminated site (KO) (Table 7). The highest EF values for $\mathrm{Cd}$ (28.1), $\mathrm{Pb}$ (54.3) and $\mathrm{Zn}$ (12.07) were detected for the V. myrtillus at site M and the highest EF for Mn (2.02) was found for the bilberry at Katowice-Kostuchna (site K; Table 7).

The greatest concentration of ascorbic acid was detected in the leaves of the V. myrtillus at the most contaminated $\mathrm{M}$ site (3.32 $\mathrm{mg} \mathrm{g}^{-1}$ fresh weight) (Fig. 2).

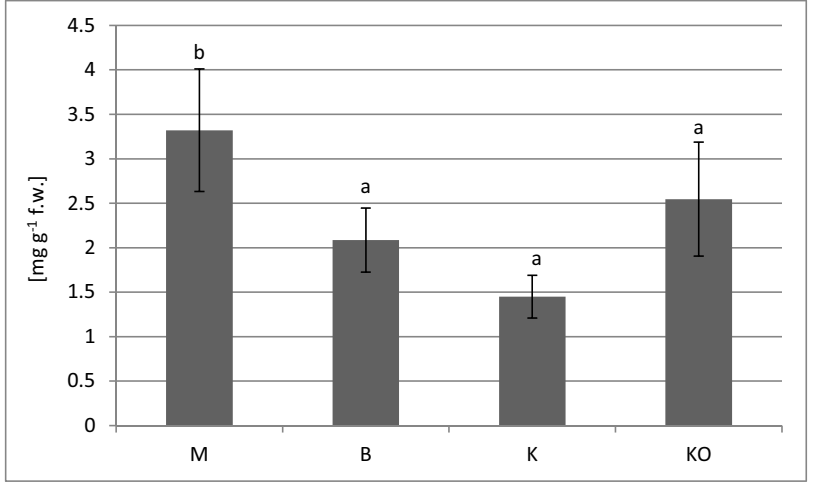

Fig. 2 Ascorbic acid contents ( $\mathrm{mg} \mathrm{g}^{-1}$ fresh weight) in $V$. myrtillus leaves (mean values $\pm \mathrm{SD}$ ). Different letters above the columns indicate significant differences $(p<0.05)$. M-Miasteczko Śląskie, BBukowno, K-Katowice-Kostuchna, KO-Kokotek

This dependence was confirmed by a positive correlation between the ascorbic acid content and the concentrations of $\mathrm{Cd}, \mathrm{Pb}$ and $\mathrm{Zn}$ in the bilberry leaves (Table 8 and Fig. 4). The lowest content of ascorbic acid was detected at site K (Fig. 2). There was also a strong negative correlation between both the $\mathrm{Mn}$ and $\mathrm{Mg}$ and AA content in the bilberry leaves (Table 8 and Fig. 4).

Although there were no significant differences in the total phenols between the contaminated and non-contaminated sites (Fig. 3), the lowest value of the total phenolic content (490.77 $\mathrm{mg} \mathrm{g}^{-1}$ d.w.) was recorded at Bukowno (B), where the highest Fe concentration was detected in the leaves (Table 4 and Fig. 3). Finally, there were significant negative correlations between the total phenolic content and the 
Table 8 The correlation coefficients between metal concentration and ecophysiological parameters in the V. myrtillus leaves ( $p<0.05)$

\begin{tabular}{|c|c|c|c|c|c|c|c|c|c|c|c|c|}
\hline & $\mathrm{Al}$ & $\mathrm{Ca}$ & $\mathrm{Cd}$ & $\mathrm{Cu}$ & $\mathrm{Fe}$ & $\mathrm{K}$ & $\mathrm{Mg}$ & $\mathrm{Mn}$ & $\mathrm{Na}$ & $P$ & $\mathrm{~Pb}$ & $\mathrm{Zn}$ \\
\hline Ascorbic acid & NS & NS & $0.92^{*}$ & NS & NS & NS & $-0.80 *$ & $-0.70^{*}$ & NS & NS & $0.92 *$ & $0.92 *$ \\
\hline Soluble phenolics & NS & NS & NS & NS & $-0.82 *$ & NS & NS & NS & NS & NS & NS & NS \\
\hline
\end{tabular}

NS not significant

*Significant

Fig. 3 Changes of soluble phenolics ( $\mathrm{mg} \mathrm{g}^{-1}$ dry weight) in $V$. myrtillus leaves (mean values $\pm S D$ ). Different letters above the columns indicate significant differences $(p<0.05)$. M-Miasteczko Śląskie, BBukowno, K-Katowice-Kostuchna, KO-Kokotek

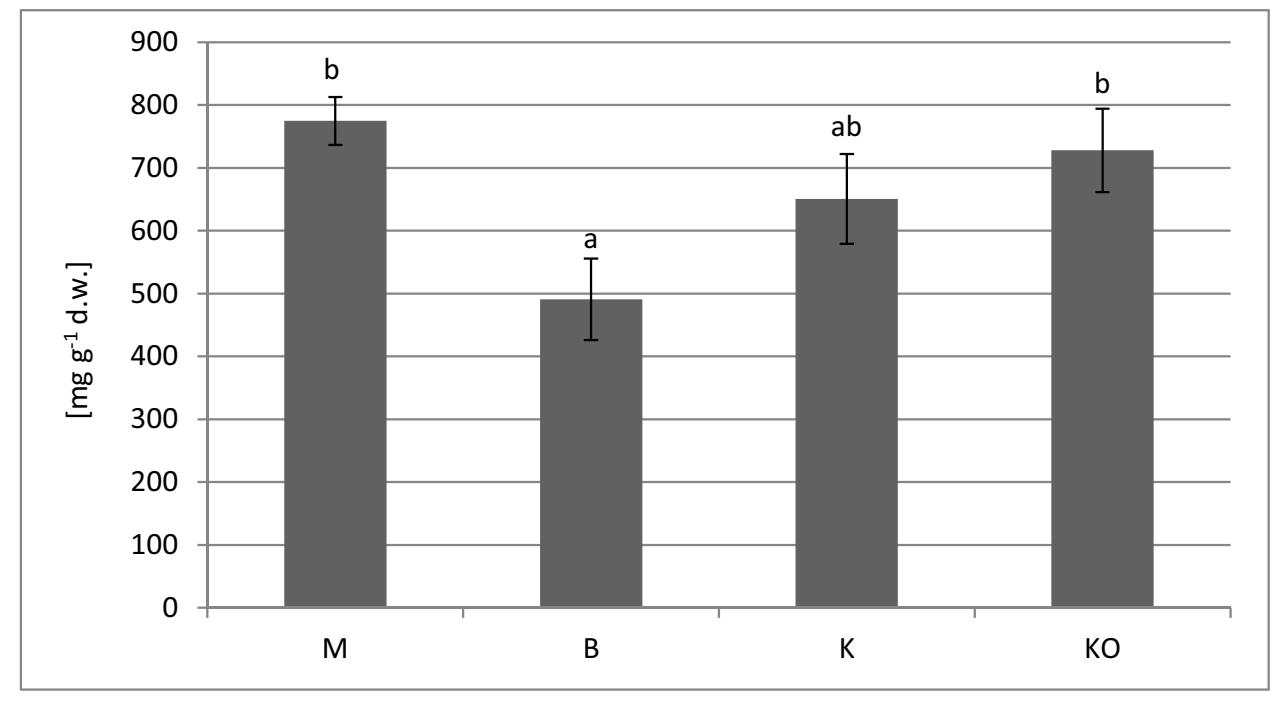

$1 ; 25.3 \%$ by axis 2 ) of the variability for the ecophysiological responses of the Vaccinium myrtillus leaves (Fig. 4).

\section{Discussion}

The results of study showed that Vaccinium myrtillus appears to be a good bioindicator for metal pollution because it has higher values in the areas that are polluted with the most toxic trace elements with the exception of Mn (see also $[7,25]$. The highest concentrations of toxic trace elements were usually much higher than the values that are considered to be sufficient or normal and they exceeded the toxic levels for plants (according to [26, 27]. Other field studies in heavily polluted areas near a $\mathrm{Ni}-\mathrm{Cu}$ smelter showed that bilberry was tolerant to high metal levels and was also not significantly stressed [28]. In this study, the TF $>1$ for Mn (highest values) and $\mathrm{Zn}$ was observed at all investigated sites except for $\mathrm{Cd}$ at the control site (Kokotek-KO). A TF factor $>1$ indicates that a plant efficiently translocates metals from the roots to the shoots. According to [29, 30] and [31], a TF $>1$ indicates a metal extraction potential, which, according to [32], makes such plants effective phytoremediators. TF values higher than 1 mean that a plant acts as an accumulator [31], which is particularly evident in the case of Mn. Many authors (e.g., $[6,7,9,25,33]$ have confirmed the ability of 
V. myrtillus to readily accumulate $\mathrm{Mn}$. The relatively low TF values of bilberry for $\mathrm{Pb}$ may result from that it is a toxic trace metal with limited mobility that is first accumulated in the roots. Additionally, low TF values for this metal indicate its potential to stabilise in the soil [34].

The highest enrichment factors in bilberry were found for $\mathrm{Pb}$. Additionally, an $\mathrm{EF}>2$ was observed for $\mathrm{Zn}, \mathrm{Cd}$ and Mn, which, according to [35], means that bilberry might be enriched in these metals; this enrichment is mainly associated with their presence for many years in the vicinity of the activity of the zinc smelter and Mining and Metallurgical Plant and the high concentrations of $\mathrm{Cd}, \mathrm{Pb}$ and $\mathrm{Zn}$ in the upper soil layers in these areas.

The relationship between the environment and bilberry that is based on the content of the individual components in a plant should be treated as approximate. Therefore, it is necessary to acquire new methods for interpreting the chemical composition of plants, which will permit a more precise description of the relationship between a plant and the environment. Such methods include the ANE (accumulation of nutrient elements) thanks to which it is possible to characterise the habitat richness with the components that are available to plants and the state of supplying plants with minerals, which would be much better than using the conventional interpretation of the content of each component separately [21, 32]. In this study, unambiguously interpreting the content of macro-elements in V. myrtillus was difficult. Only the ANE method permitted the observation that in the same area in which the highest value of the sum of the trace elements (and percentage of $\mathrm{Cd}, \mathrm{Pb}, \mathrm{Zn}$ ) was found, the sum of the accumulated macronutrients was definitely lower compared to the other sampling sites. The content of macro-elements in the bilberry shoots, which was interpreted using the ANE method, indicated that site M (near the zinc smelter) is a habitat that is less rich in nutrients than the other areas that were selected for the research.

In plants that are exposed to toxic trace metals, various non-enzymatic antioxidants accumulate and these are involved in detoxifying the trace metal and ROS-scavenging pathways [36]. Antioxidant molecules including ascorbic acid and phenolic compounds inhibit oxidation and play crucial roles in the stress responses [37, 38].

Apart from the basic role of ascorbic acid (AsA) in protecting plants from the deleterious effects of ROS, AsA also plays an essential role in the growth and normal functioning of plants, it protects lipids and proteins and induces plant growth, photosynthesis, transpiration and photosynthetic pigments [39-41]. Increased levels of $\mathrm{Cd}, \mathrm{Pb}$ and $\mathrm{Zn}$ generally resulted in a higher ascorbic acid content in the leaves of $V$. myrtillus, and these results are consistent with previous studies on the accumulation of toxic trace metals in V. vitis-idaea [6]. A similar relationship between the increase in AsA content due to the increased concentration of various toxic trace metals was also found by [42-44]; these results indicated that increased levels of ascorbic acid participate in the plant responses to toxic trace metal accumulation and have a positive effect on pollution tolerance by plants $[45,46]$. Simultaneously, an excess Mn concentration significantly reduced the content of ascorbic acid. This phenomenon has been observed by many authors [6, 42, 46-49], which suggests that AsA might be one of the most important compounds in the response to Mn stress and the adaptation of plants to the environment, especially for bilberry, which has been reported to accumulate high levels of $\mathrm{Mn}$. The decrease in the ascorbic acid content in response to Mn stress could be explained by the fact that ascorbic acid and its metabolic precursors give rise to oxalic acid; oxalate is involved in the detoxification of toxic metals [42, 50, 51] and could enhance the defences against Mn stress in bilberry leaves.

The leaves of $V$. myrtillus are a rich source of a variety of secondary metabolites such as phenolic compounds, which are responsible for the adaptation of plants to the environment [16]. Plants can synthesise phenolic compounds as a protective mechanism against adverse environmental conditions in order to remove ROS from reduce oxidative stress and chelate toxic metals through functional groups, both hydroxyl and carboxylic acid $[52,53]$. Additionally, phenolic compounds can participate in the ROS-scavenging mechanisms by cooperating with the antioxidant enzymes, especially with the peroxidases and superoxide dismutase [23, 52]. Many authors [16, 38, 52, 53 ] have reported that exposure to toxic trace metals increases the production of phenolic compounds in plants. However, in this study, the level of phenolic compounds did not increase in the presence of the investigated toxic trace metals. Additionally, a decrease of phenolic compounds under Fe contamination was observed. Moreover, [54] found a decrease in the phenol content in Cd-treated okra plants. As [55] suggested, the lack of an increase of phenolic compounds in blueberry leaves might have been caused by an excessive accumulation of toxic metals, especially $\mathrm{Cd}, \mathrm{Pb}$ and $\mathrm{Zn}$, which could impair the antioxidative system responses based on phenolics in such way that plants are not able to synthesise new phenols. Additionally, [55] reported that the highest cadmium exposure did not significantly affect the total phenolic compounds in Erica andevalensis leaves and [56] they did not observe an increase of the total phenolic compounds in Spartina densiflora under high cadmium exposure. However, as in this study, they found an increased ascorbic acid content in response to cadmium.

\section{Conclusions}

The results confirmed that Vaccinium myrtillus L. is one of the species of the conifer forest understorey that can grow in metal-polluted areas and that the contamination changes its ecophysiological responses. An EF $>2$ was found for 
$\mathrm{Cd}, \mathrm{Pb}, \mathrm{Zn}$ and $\mathrm{Mn}$, which suggests that bilberries might be enriched in these metals and could act as indicators of metal contamination of the soil. According to the translocation factor, V. myrtillus acted as an accumulator of $\mathrm{Cd}$, $\mathrm{Zn}$ and especially for $\mathrm{Mn}$, which makes this species good for phytoremediation.

The increased content of toxic trace metals caused disturbances in the mutual relationships of the examined elements and had a negative effect on the mineral composition of $V$. myrtillus.

This study suggests that a non-enzymatic antioxidant such as ascorbic acid could be a good biomarker for the oxidative stress that is caused by toxic metals and could be used as a warning indicator for forest ecosystems. However, the role of various types of antioxidants in detoxifying toxic trace metals has not yet been fully explained, especially for plants that are growing in natural conditions in which metals do not act as a single factor. Therefore, it is important to conduct this type of investigation to identify vital clues for improving pollution biomonitoring in forest ecosystems.

Authors' Contributions Study concept and design: Marta KandzioraCiupa. Analysis and interpretation of data: Marta Kandziora-Ciupa, Marzena Dabioch and Aleksandra Nadgórska-Socha. Statistical analysis: Marta Kandziora-Ciupa. Drafting of the manuscript: Marta Kandziora-Ciupa. Critical revision of the manuscript for important intellectual content: Aleksandra Nadgórska-Socha. All of the authors read and approved the final manuscript.

Funding This research did not receive any specific grant from funding agencies in the public, commercial or not-for-profit sectors.

Data Availability The data presented in this study are available on request from the corresponding author. The data are not publicly available due to privacy restrictions.

\section{Declarations}

Ethics Approval This article does not contain any studies with human participants or animals that were performed by any of the authors.

Animal Research Not applicable.

Plant Reproducibility Not applicable.

Consent to Participate Informed consent was obtained from all individual participants included in the study.

Consent for Publication Informed consent was obtained from all individual participants included in the study.

Conflict of Interest The authors declare that they have no conflict of interest.

Open Access This article is licensed under a Creative Commons Attribution 4.0 International License, which permits use, sharing, adaptation, distribution and reproduction in any medium or format, as long as you give appropriate credit to the original author(s) and the source, provide a link to the Creative Commons licence, and indicate if changes were made. The images or other third party material in this article are included in the article's Creative Commons licence, unless indicated otherwise in a credit line to the material. If material is not included in the article's Creative Commons licence and your intended use is not permitted by statutory regulation or exceeds the permitted use, you will need to obtain permission directly from the copyright holder. To view a copy of this licence, visit http://creativecommons. org/licenses/by/4.0/.

\section{References}

1. Jamnická G, Vál'ka J, Bublinec E, Bublinec E (2013) Heavy metal accumulation and distribution in forest understory herb species of Carpathian beech ecosystems. Chem Speciat Bioavailab 25:209 215. https://doi.org/10.3184/095422913X13785568683285

2. Rademacher P (2003) Atmospheric heavy metals and forest ecosystems, Work Report, No. 2003/12, Federal Research Centre for Forestry and Forest Products (BFH), Institute for World Forestry, Hamburg. http://nbn-resolving.de/urn:nbn:de:gbv:253-201002dk040080-3

3. ICP Forests Manual. http://icp-forests.net/page/icp-forests-manual. Accessed 8 Oct 2021

4. Liu JJ, Wei Z, Li JH (2014) Effects of copper on leaf membrane structure and root activity of maize seedling. Bot Stud 55:47. https://doi.org/10.1186/s40529-014-0047-5

5. Rodríguez A, Kouki J (2015) Emulating natural disturbance in forest management enhances pollination services for dominant Vaccinium shrubs in boreal pine-dominated forests. For Ecol Manag 350:1-12. https://doi.org/10.1016/j.foreco.2015.04.029

6. Kandziora-Ciupa M, Nadgórska-Socha A, Barczyk G, Ciepał R (2017) Bioaccumulation of heavy metals and ecophysiological responses to heavy metal stress in selected populations of Vaccinium myrtillus L. and Vaccinium vitis-idaea L. Ecotoxicology 26:966-980. https://doi.org/10.1007/s10646-017-1825-0

7. Eeva T, Holmström H, Espín S et al (2018) Leaves, berries and herbivorous larvae of bilberry Vaccinium myrtillus as sources of metals in food chains at a $\mathrm{Cu}-\mathrm{Ni}$ smelter site. Chemosphere 210:859-866. https://doi.org/10.1016/j.chemosphere.2018.07.099

8. Uhlig C, Junttila O (2001) Airborne heavy metal pollution and its effects on foliar elemental composition of Empetrum hermaphroditum and Vaccinium myrtillus in Sør-Varanger, northern Norway. Environ Pollut 114:461-469. https://doi.org/10.1016/ S0269-7491(00)00225-6

9. Salemaa M, Derome J, Helmisaari H-S et al (2004) Element accumulation in boreal bryophytes, lichens and vascular plants exposed to heavy metal and sulfur deposition in Finland. Sci Total Environ 324:141-160. https://doi.org/10.1016/j.scitotenv.2003.10. 025

10. Taulavuori K, Laine K, Taulavuori E (2013) Experimental studies on Vaccinium myrtillus and Vaccinium vitis-idaea in relation to air pollution and global change at northern high latitudes: a review. Environ Exp Bot 87:191-196. https://doi.org/10.1016/j. envexpbot.2012.10.002

11. Fryzova R, Pohanka M, Martinkova P et al (2018) Oxidative stress and heavy metals in plants. In: de Voogt P (ed) Reviews of environmental contamination and toxicology, vol 245. Springer International Publishing, Cham, pp 129-156

12. Šiukšta R, Bondzinskaitė S, Kleizaitė V et al (2019) Response of Tradescantia plants to oxidative stress induced by heavy metal pollution of soils from industrial areas. Environ Sci Pollut Res Int 26:44-61. https://doi.org/10.1007/s11356-018-3224-3 
13. Anjum SA, Tanveer M, Hussain S et al (2015) Cadmium toxicity in Maize (Zea mays L.): consequences on antioxidative systems, reactive oxygen species and cadmium accumulation. Environ Sci Pollut Res 22:17022-17030. https://doi.org/10.1007/ s11356-015-4882-z

14. Emamverdian A, Ding Y, Mokhberdoran F, Xie Y (2015) Heavy metal stress and some mechanisms of plant defense response. Sci World J 2015:e756120. https://doi.org/10.1155/2015/756120

15. Upadhyay R, Chaurasia JK, Tiwari KN, Singh K (2014) Antioxidant property of aerial parts and root of Phyllanthus fraternus Webster, an important medicinal plant. ScientificWorldJournal 2014:692392. https://doi.org/10.1155/2014/692392

16. Białońska D, Zobel AM, Kuraś M et al (2006) Phenolic compounds and cell structure in bilberry leaves affected by emissions from a $\mathrm{Zn}-\mathrm{Pb}$ smelter. Water Air Soil Pollut 181:123. https://doi. org/10.1007/s11270-006-9284-x

17. Hu Y, Wang D, Wei L et al (2014) Bioaccumulation of heavy metals in plant leaves from Yan'an city of the Loess Plateau, China. Ecotoxicol Environ Saf 110:82-88. https://doi.org/10.1016/j. ecoenv.2014.08.021

18. Morkunas I, Woźniak A, Mai VC et al (2018) The role of heavy metals in plant response to biotic stress. Molecules 23(9): 2320. https://doi.org/10.3390/molecules23092320

19. Kandziora-Ciupa M, Nadgórska-Socha A, Barczyk G (2021) The influence of heavy metals on biological soil quality assessments in the Vaccinium myrtillus L. rhizosphere under different field conditions. https://doi.org/10.1007/s10646-021-02345-1

20. Lin A, Zhang X, Zhu Y-G, Zhao F-J (2008) Arsenate-induced toxicity: effects on antioxidative enzymes and DNA damage in Vicia faba. Environ Toxicol Chem 27:413-419. https://doi.org/ 10.1897/07-266R.1

21 Ostrowska A, Porębska G (2002) The plant chemical composition, its interpretation and use in environmental protection. Institute of Environmental Protection, Warszawa ([in Polish])

22. Serbula SM, Miljkovic DD, Kovacevic RM, Ilic AA (2012) Assessment of airborne heavy metal pollution using plant parts and topsoil. Ecotoxicol Environ Saf 76:209-214. https://doi.org/ 10.1016/j.ecoenv.2011.10.009

23. Kováčik J, Bačkor M (2007) Phenylalanine ammonia-lyase and phenolic compounds in chamomile tolerance to cadmium and copper excess. Water Air Soil Pollut 185:185-193. https://doi.org/10. 1007/s11270-007-9441-x

24. Keller T, Schwager H (1977) Air pollution and ascorbic acid. Eur J Pathol Ger Fed Repub Of 7:6

25. Mróz L, Demczuk M (2010) Contents of phenolics and chemical elements in bilberry (Vaccinium myrtillus L.) leaves from copper smelter area (SW Poland). Pol J Ecol 58:475-486

26. Markert B (1992) Presence and significance of naturally occurring chemical elements of the periodic system in the plant organism and consequences for future investigations on inorganic environmental chemistry in ecosystems. Vegetatio 103:1-30. https://doi. org/10.1007/BF00033413

27 Kabata-Pendias A, Pendias H (2010) Trace elements in soils and plants, 4th edn. CRC Press, Boca Raton. https://doi.org/10.1201/ b10158

28. Zvereva EL, Kozlov MV (2005) Growth and reproduction of dwarf shrubs, Vaccinium myrtillus and V. vitis-idaea, in a severely polluted area. Basic Appl Ecol 6:261-274. https://doi.org/10. 1016/j.baae.2004.11.003

29. Wei C-Y, Chen T-B (2006) Arsenic accumulation by two brake ferns growing on an arsenic mine and their potential in phytoremediation. Chemosphere 63:1048-1053. https://doi.org/10.1016/j. chemosphere.2005.09.061

30. Usman ARA, Lee SS, Awad YM et al (2012) Soil pollution assessment and identification of hyperaccumulating plants in chromated copper arsenate (CCA) contaminated sites, Korea. Chemosphere 87:872-878. https://doi.org/10.1016/j.chemosphere.2012.01.028

31. Kumar N, Bauddh K, Kumar S et al (2013) Accumulation of metals in weed species grown on the soil contaminated with industrial waste and their phytoremediation potential. Ecol Eng Part A 61:491-495. https://doi.org/10.1016/j.ecoleng.2013.10.004

32. Nadgórska-Socha A, Kandziora-Ciupa M, Ciepał R (2015) Element accumulation, distribution and phytoremediation potential in selected metallophytes growing in a contaminated area. Environ Monit Assess 187:441. https://doi.org/10.1007/ s10661-015-4680-6

33. Reimann C, Koller F, Frengstad B et al (2001) Comparison of the element composition in several plant species and their substrate from a $1500000-\mathrm{km} 2$ area in Northern Europe. Sci Total Environ 278:87-112. https://doi.org/10.1016/s0048-9697(00)00890-1

34. Yoon J, Cao X, Zhou Q, Ma LQ (2006) Accumulation of Pb, Cu and $\mathrm{Zn}$ in native plants growing on a contaminated Florida site. Sci Total Environ 368:456-464. https://doi.org/10.1016/j.scito tenv.2006.01.016

35. Mingorance MD, Valdés B, Oliva SR (2007) Strategies of heavy metal uptake by plants growing under industrial emissions. Environ Int 33:514-520. https://doi.org/10.1016/j.envint.2007.01.005

36. Mishra B, Sangwan RS, Mishra S et al (2014) Effect of cadmium stress on inductive enzymatic and nonenzymatic responses of ROS and sugar metabolism in multiple shoot cultures of Ashwagandha (Withania somnifera Dunal). Protoplasma 251:1031-1045. https://doi.org/10.1007/s00709-014-0613-4

37. Racchi ML (2013) Antioxidant defenses in plants with attention to Prunus and Citrus spp. Antioxidants 2:340-369. https://doi.org/ 10.3390/antiox 2040340

38. Kısa D, Elmastaş M, Öztürk L, Kayır Ö (2016) Responses of the phenolic compounds of Zea mays under heavy metal stress. Appl Biol Chem 6:813-820. https://doi.org/10.1007/ s13765-016-0229-9

39. Ahmad P, Umar S, Sharma S (2010) Mechanism of free radical scavenging and role of phytohormones in plants under abiotic stresses. In: Ashraf M, Ozturk M, Ahmad MSA (eds) Plant Adaptation and Phytoremediation. Springer, Netherlands, Dordrecht, pp 99-118

40. Akram NA, Shafiq F, Ashraf M (2017) Ascorbic acid-a potential oxidant scavenger and its role in plant development and abiotic stress tolerance. Front Plant Sci 8:613. https://doi.org/10.3389/ fpls.2017.00613

41. Alamri SA, Siddiqui MH, Al-Khaishany MY, et al (2018) Ascorbic acid improves the tolerance of wheat plants to lead toxicity. $\mathrm{J}$ Plant Interact

42. Demirevska-Kepova K, Simova-Stoilova L, Stoyanova $\mathrm{Z}$ et al (2004) Biochemical changes in barley plants after excessive supply of copper and manganese. Environ Exp Bot 3:253-266. https://doi.org/10.1016/j.envexpbot.2004.02.004

43. Meerabai G, Ramana C, Rasheed M (2012) Effect of industrial pollutants on physiology of Cajanus cajan (L.)-Fabaceae. Agris -Line Pap Econ Inform 2:1901-1906. https://doi.org/10.6088/ijes. 00202030072

44. Rai PK, Panda LLS, Chutia BM, Singh MM (2013) Comparative assessment of air pollution tolerance index (APTI) in the industrial (Rourkela) and non-industrial area (Aizawl) of India: An ecomanagement approach. Afr J Environ Sci Technol 7:944-948. https://doi.org/10.4314/ajest.v7i10

45. Rai PK, Panda LLS (2014) Dust capturing potential and air pollution tolerance index (APTI) of some roadside tree vegetation in Aizawl, Mizoram, India: an Indo-Burma hot spot region. Air Qual Atmosphere Health 7:93-101. https://doi.org/10.1007/ s11869-013-0217-8

46. Nadgórska-Socha A, Kandziora-Ciupa M, Ciepał R, Barczyk G (2016) Robinia pseudoacacia and Melandrium album in trace 
elements biomonitoring and air pollution tolerance index study. Int J Environ Sci Technol 13:1741-1752. https://doi.org/10.1007/ s13762-016-1010-7

47. Fecht-Christoffers MM, Maier P, Horst WJ (2003) Apoplastic peroxidases and ascorbate are involved in manganese toxicity and tolerance of Vigna unguiculata. Physiol Plant 117:237-244. https://doi.org/10.1034/j.1399-3054.2003.00022.x

48. Ducic T, Polle A (2005) Transport and detoxification of manganese and copper in plants. Braz J Plant Physiol 17:103-112. https://doi.org/10.1590/S1677-04202005000100009

49. Shi Q, Bao Z, Zhu Z et al (2005) Silicon-mediated alleviation of Mn toxicity in Cucumis sativus in relation to activities of superoxide dismutase and ascorbate peroxidase. Phytochemistry 66:1551-1559. https://doi.org/10.1016/j.phytochem.2005.05.006

50. Kostman TA, Tarlyn NM, Loewus FA, Franceschi VR (2001) Biosynthesis of L-ascorbic acid and conversion of carbons 1 and 2 of L-ascorbic acid to oxalic acid occurs within individual calcium oxalate crystal idioblasts. Plant Physiol 125:634-640. https://doi. org/10.1104/pp.125.2.634

51. Xu H-W, Ji X-M, He Z-H et al (2006) Oxalate accumulation and regulation is independent of glycolate oxidase in rice leaves. J Exp Bot 57:1899-1908. https://doi.org/10.1093/jxb/erj131

52. Manquián-Cerda K, Cruces E, Escudey M et al (2018) Interactive effects of aluminum and cadmium on phenolic compounds, antioxidant enzyme activity and oxidative stress in blueberry (Vaccinium corymbosum L.) plantlets cultivated in vitro. Ecotoxicol
Environ Saf 150:320-326. https://doi.org/10.1016/j.ecoenv.2017. 12.050

53. Chen S, Wang Q, Lu H et al (2019) Phenolic metabolism and related heavy metal tolerance mechanism in Kandelia Obovata under Cd and Zn stress. Ecotoxicol Environ Saf 169:134-143. https://doi.org/10.1016/j.ecoenv.2018.11.004

54. Mousavi A, Pourakbar L, SiavashMoghaddam S, PopovićDjordjević J (2021) The effect of the exogenous application of EDTA and maleic acid on tolerance, phenolic compounds and cadmium phytoremediation by okra (Abelmoschus esculentus L.) exposed to Cd stress. J Environ Chem Eng 9:105456. https://doi. org/10.1016/j.jece.2021.105456

55. Márquez-García B, Fernández-Recamales MA, Córdoba F (2012) Effects of cadmium on phenolic composition and antioxidant activities of Erica andevalensis. https://doi.org/10.1155/2012/ 936950

56. Domínguez DM, García FC, Raya AC, Santiago RT (2010) Cadmium-induced oxidative stress and the response of the antioxidative defense system in Spartina densiflora. Physiol Plant. https:// doi.org/10.1111/j.1399-3054.2010.01368.x

Publisher's Note Springer Nature remains neutral with regard to jurisdictional claims in published maps and institutional affiliations. 